\title{
Enzootic nasal \\ adenocarcinoma in small ruminants in Jordan
}

\author{
W. Hananeh*, M. Daradka, Z. B. Ismail, R. Mukbel and M. El-Ekish
}

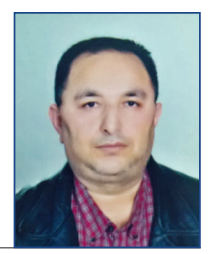

\begin{abstract}
Enzootic nasal adenocarcinoma (ENA) is a viral-associated tumor of the secretory epithelium of the nasal passages of small ruminants. The tumor is locally invasive but not metastatic. Although disease prevalence (up to $15 \%$ ) and geographic distribution have been reported in the literature throughout most of the world (except Australia and New Zealand), the disease has until now remained unreported in Jordan. In this report, we describe the occurrence, clinical signs, radiographic signs and pathological features of the disease in a series of cases in Awassi sheep (3 cases) and Damascus breed goats (2 cases) for the first time in Jordan. Overall, the affected
\end{abstract}

animals were adults (3-5 years of age), all females, with variable degrees of facial and nasal deformities resulting in difficulty in respiration. Radiographic examination of the skull revealed soft tissue density mass originating in the nasal turbinate and invading the surrounding nasal structures. Cytological examination of fine needle aspirate indicated low-grade carcinoma. All animals were humanely euthanized and the nasal passages were explored. Variable size masses were removed and histopathological examination confirmed the diagnosis of enzootic nasal adenocarcinoma.

Key words: Awassi sheep; Damascus goats; Nasal tumor; Retrovirus

\section{Introduction}

Enzootic nasal adenocarcinoma (ENA), a neoplasm of the nasal passages, is caused by enzootic nasal tumor virus (ENTV) (Stowe et al., 2012; Walsh et al., 2013; Sid et al., 2018). The virus is genetically similar to Jaagsiekte sheep retrovirus (JSRV) that causes ovine pulmonary adenocarcinoma (OPA)
(De las Heras et al., 1995; Palmarini et al., 1999; Svara et al., 2006; Darrick et al., 2011). The virus is most likely to be transmitted between animals via nasal discharges. Experimentally, the disease has been successfully induced in goats and sheep by intranasal inoculation with nasal exudates and cell and bacteria-free

Wael HANANEH*, DVM, MSc, Dipl. ACVP, Associate Professor, (Corresponding author, e-mail: whananeh@just.edu.jo), Mousa DARADKA, DVM, PhD, Associate Professor, Zuhair Bani ISMAIL, DVM, ABVP, Full Profesor, Rami MUKBEL, DVM, MSc, PhD, Associate Proefessor, Myassar EL-EKISH, DVM, ABVP, Associate Professor, Faculty of Veterinary Medicine, Jordan University of Science and Technology, Irbid, Jordan 
tumor filtrate, respectively (De las Heras et al., 1995; De las Heras et al., 2003; Ortín et al., 2003; Darrick et al., 2011). The tumor is usually locally invasive and arises from the nasal turbinates leading to partial to complete occlusion of the nasal passages (De las Heras et al., 2003; Walsh et al., 2013). No metastasis has been reported. Clinically, the tumor is characterized by a unilateral or bilateral nasal obstruction and facial distortion associated with variable degrees of mucopurulent nasal discharge, dyspnea and progressive weight loss (De las Hares et al., 2003). The disease can be diagnosed based on previous knowledge of the presence of the disease in the geographic area and clinical signs (Svara et al., 2006). The diagnosis then can be confirmed in live animals by radiographic examination and cytology of tissue aspirates. In dead animals, the diagnosis is confirmed using histopathological examination and molecular methods such as PCR (Svara et al., 2006).

\section{Cases Details}

Over a period of two years, three Awassi sheep and two Damascus breed goats were presented to the Veterinary Health Center of Jordan University of Science and Technology for evaluation of difficult respiration and nasal/ facial distortion. The main complaints in all animals were variable degrees of respiratory difficulties and facial distortion.

Animals were subjected to complete and comprehensive physical examination at presentation, including rectal temperature, heart rate, respiration rate and general body condition. General physical examination of all sheep revealed normal temperature and heart rate, while the respiration rate was increased with stridor. All affected animals were adult females (3-5 years of age). Animals were in poor body condition and appeared weak. Mild to moderate inspiratory/ expiratory dyspnea characterized by loud respiration was found. One of the sheep was presented with a severely distorted left frontal region with skin hyperkeratosis, wool loss and abnormal hard growth resembling a horn. Another sheep was presented with a large traumatized polyp-like structure extending from its right nostril (Fig. 1 ). The third sheep and two goats were presented with variable degrees of facial distortion (Fig. 2).

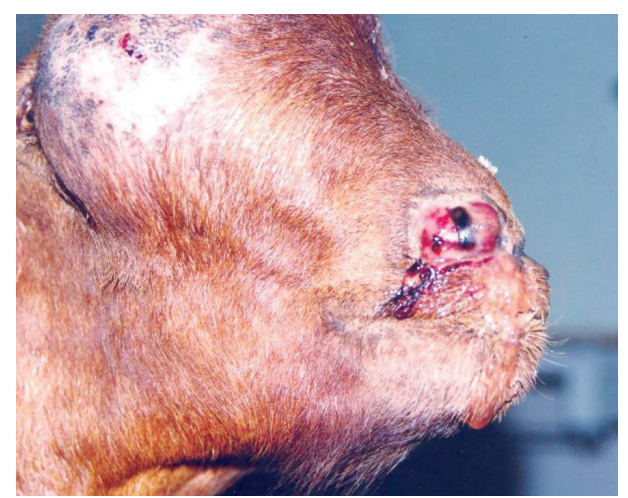

Fig. 1. Enzootic nasal adenocarcinoma in a sheep with a unilateral facial distortion. Notice the small mass protruding from the right nostril

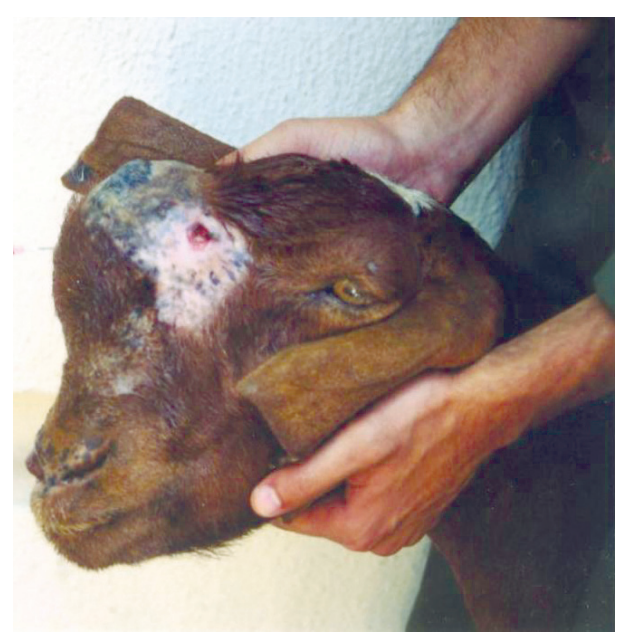

Fig. 2. Enzootic nasal adenocarcinoma in a goat with facial distortion 
Two radiographic views (lateral and ventrodorsal) of the skull were taken of all affected animals using a portable digital radiographic machine. Radiographic examination of the skull revealed a large, soft-tissue density mass originating in the nasal turbinate and invading the surrounding nasal structures (Fig. 3).

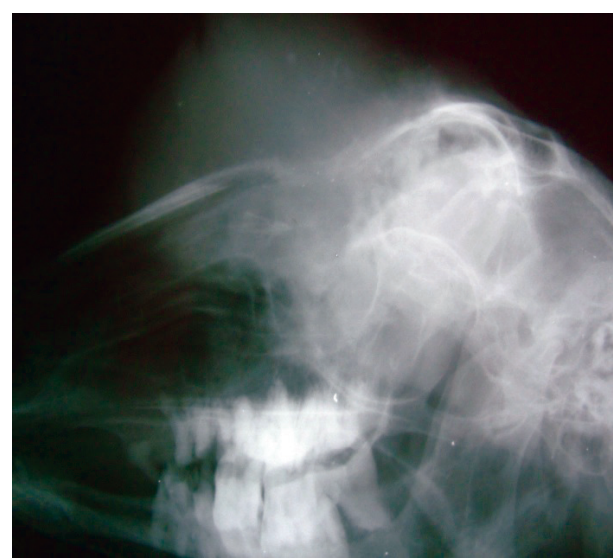

Fig. 3. Lateral radiograph of the head of a goat with enzootic nasal adenocarcinoma. Notice the soft tissue density mass unilaterally filling the nasal passages including sinuses and turbinates

Tissue specimens were aspirated from live animals for cytology using a 20-gauge needle attached to a $10 \mathrm{~mL}$ syringe. Tissue specimens were prepared and stained using Giemsa stain. Cytological examination of the fine needle aspirate indicated low-grade carcinoma and a preliminary diagnosis of enzootic nasal adenocarcinoma was made.

Based on the poor prognosis of the cases, humane euthanasia of the affected animals was proposed. Animals were humanely euthanatized by intravenous injection of anesthetic overdose (Pentobarbital, Intervet, Canada). Animals were then subjected to complete necropsy examination. Tissue specimens from the nasal masses were placed in $10 \%$ buffered formalin solution and transported to the laboratory for routine histopathology examination. Slides were stained with H\&E stain and examined using light microscopy. Gross, white to gray, space occupying, highly destructive, locally invasive neoplastic masses originating in the ethmoid turbinate were present in either the left or right nasal cavities. The size of lesions varied from a few to over 10 centimeters in diameter. The lesions infiltrated in either direction, extending to the pharynx and also infiltrating the cribriform plate in some cases. Histopathological examination confirmed the diagnosis of enzootic nasal adenocarcinoma. The neoplastic mass was unencapsulated, multilobular, destructive and locally invasive. It was composed of densely cellular neoplastic cells supported by fine fibrovascular stroma. The neoplastic cells were moderately differentiated forming acini, tubules and/or trabeculae (Fig. 4). Neoplastic cells were columnar tocuboidal with variably distinct cell borders. They had an abundant, faintly eosinophilic and finely granular cytoplasm. Some cells exhibited a vacuolated cytoplasm. The majority of these cells contained round to oval with moderate basophilic nuclei situated basilary, while some centrally located nuclei were also present. They

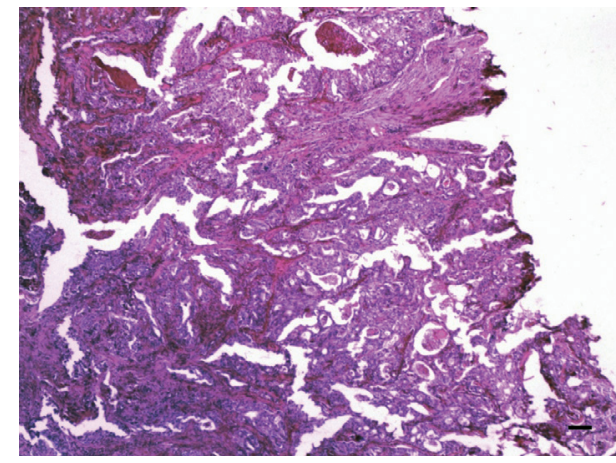

Fig. 4. Enzootic nasal adenocarcinoma in a sheep. The neoplastic cells are moderately differentiated forming acini, tubules and/or trabeculae of columnar and cuboidal cells supported by fibrovascular stroma. H\&E. Bar = $100 \mu \mathrm{m}$ 
contained one or more distinct nucleoli. Tumor syncytial cells and mitotic figures were occasional seen. The fibrovascular stroma were variably infiltrated with moderate numbers of mononuclear cells, primarily lymphocytes. Scattered areas of degeneration and necrosis with a few degenerate and live neutrophils were seen. No tumor cells were present in the regional lymph nodes.

\section{Discussion}

Enzootic nasal adenocarcinoma, a contagious, viral-associated tumor of the nasal passages in sheep and goats is reported here for the first time in Jordan. The epidemiological data, clinical signs, radiographic signs and histopathological findings are all inline with those reported in literature for ENA (Stowe et al., 2012; Maxie, 2015), though ENT has also been diagnosed in apparently healthy sheep with no apparent clinical signs (Kawasako et al., 2005). In European and African countries, the disease has been reported with variable prevalence rates ranging from $0.1 \%$ to $15 \%$ (Charray et al., 1985; De las Heras et al., 2003). Although the five cases described here belong to different flocks located in northern Jordan, the disease can be considered widely spread among the sheep population in Jordan as the diagnosis of ENT depends mainly on gross and/or histopathological findings. Detection of the EITV genome in apparently health sheep denoted that those sheep play an important role in the pathogenesis of this disease, since they are considered a potential reservoir for the causative agent. Recently, a novel one-tube real-time RT-PCR (RTqPCR) method for the detection and quantification of ENTV-2 in nasal swabs was developed (Apostolidi et al., 2019). This application will help in ante mortem diagnosis, disease surveillance, and/or control programs for the disease.
In Jordan, comprehensive epidemiological and risk assessment studies are needed and must be conducted to further characterize the disease and its patterns. More importantly, the impact of the disease on the economic status of sheep and goat farms must be determined in order to vitalize efforts to control the disease at the national level. As a result of this publication, veterinarians in Jordan must be alerted of the possibility of ENA in sheep and goats presented with dyspnea and chronic nasal discharge and potential carriers.

\section{Conflict of interest}

The authors declare that there is no conflict of interest.

\section{References}

1. APOSTOLIDI, E. D., D. PSALLA, T CHASSALEVRIS, S. C. CHAINTOUTIS, N. D. GIADINIS, V. PSYCHAS and C. I. DOVAS (2019): Development of real-time PCR-based methods for the detection of enzootic nasal tumor virus 2 in goats. Arch. Virol. 164, 707-716.

2. CHARRAY, J., N. AMAN and K. TANOH (1985): Note on an enzootic of adenocarcinoma of the pituitary nasal mucosa in Djalonke ewes. Rev. Elev. Med. Vet. Pays. Trop. 38, 406-410.

3. DARRICK, L. Y., N. M. LINNERTHPETRIK, C. L. HALBERT, S. R. WALSH, A. D. MILLER and S. K. WOOTTON (2011): Jaagsiekte sheep retrovirus and enzootic nasal tumor virus promoters drive gene expression in all airway epithelial cells of mice but only induce tumors in the alveolar region of the lungs. J. Virol. 85, 7535-7545.

4. DE LAS HERAS, M., J. GARCIA DE JALON, E. MINGUIJON, E. GRAY, P. DEWAR and J. SHARP (1995): Experimental transmission of enzootic intranasal tumors of goats. Vet. Pathol. $32,19-23$.

5. DE LAS HERAS, M., A. ORTIN, C. COUSENS, E. MINGUIJON and J. SHARP (2003): Enzootic nasal adenocarcinoma of sheep and goats. In: Jaagsiekte sheep retrovirus and lung cancer. Springer. PP. 201-223.

6. KAWASAKO, K., M. OKAMOTO, T. KUROSAWA, T. NAKADE, R. KIRISAWA, T. MIYASHOU, M. KOMINE, T. GO, S. IMAZU and N. TAKEUCHI (2005): Enzootic intranasal tumour virus infection in apparently healthy sheep in Japan. Vet. Rec. 157, 118-120. 
7. MAXIE, G. (2015): Jubb, Kennedy \& Palmer's Pathology of Domestic Animals-E-Book: Elsevier Health Sciences.

8. ORTÍN, A., C. COUSENS, E. MINGUIJON, Z. PASCUAL, M. P. DE VILLARREAL, J. M. SHARP and M. DE LAS HERAS (2003): Characterization of enzootic nasal tumour virus of goats: complete sequence and tissue distribution. J. Gen. Virol. 84, 2245-2252.

9. PALMARINI, M., J. M.SHARP, M. DE LAS HERAS and H. FAN (1999): Jaagsiekte sheep retrovirus is necessary and sufficient to induce a contagious lung cancer in sheep. J. Virol. 73, 6964-6972.

10. SID, N., N. E. H. BELALMI, L. BENHAMZA, S. OUHIDA, M. E. ZEBIRI, A. AYDOĞAN and C. LEROUX (2018): First case report of enzootic nasal adenocarcinoma in" Ouled Djellal" ewe in Algeria. Open Vet. J. 8, 9-12.

11. STOWE, D. M., K. L. ANDERSON, J. S. GUY, K. E. LINDER and C. B. GRINDEM (2012): A case of enzootic nasal adenocarcinoma in a ewe. Case Rep. Vet. Med. Article ID 347193, 4 pages. https://doi.org/10.1155/2012/347193.

12. SVARA, T., M. GOMBAC, M. VRECL, P. JUNTES, R. KOSTANJSEK, A. POGACNIK and M. POGACNIK (2006): Enzootic nasal adenocarcinoma of sheep in Slovenia. J. Vet. Med. A. Physiol. Pathol. Clin. Med. 53, 26-29.

13. WALSH, S. R., N. M. LINNERTH-PETRIK, L.Y. DARRICK, R.A.FOSTER,P.I.MENZIES,A.DIAZMÉNDEZ,H.J.CHALMERS and S.K. WOOTTON (2013): Experimental transmission of enzootic nasal adenocarcinoma in sheep. Vet. Res. 44, 66.

\section{Enzootski nazalni adenokarcinom u malih preživača u Jordanu}

Dr. sc. Wael HANANEH, dr. med. vet., Dipl. ACVP, izvanredni profesor, dr. sc. Mousa DARADKA, dr. med. vet., izvanredni profesor, dr. sc. Zuhair Bani ISMAIL, dr. med. vet., ABVP, redoviti profesor, dr. sc. Rami MUKBEL, dr. med. vet., izvanredni profesor, dr. sc. Myassar ELEKISH, dr. med. vet., ABVP, izvanredni profesor, Veterinarski fakultet, Univerzitet znanosti i tehnologije u Jordanu, Irbid, Jordan

Enzootski nazalni adenokarcinom (ENA) je tumor sekrecijskog epitela nazalnih putova etiološki povezan $s$ virusom $u$ malih preživača. Tumor je lokalno invazivan, ali ne metastazira. Premda postoje izviješća o njegovoj pojavnosti (do $15 \%$ ) i geografskoj rasprostranjenosti gotovo u cijelom svijetu (osim Australije i Novog Zelanda), u Jordanu je ostao nezamjećen. U ovom radu opisana je pojavnost, klinički znaci, rendgenološki nalazi i patološke promjene tog tumora u nizu slučajeva u Awassi pamine ovaca (3 slučaja) i pasmine koza damask (2 slučaja) prvi puta u Jordanu. Općenito, životinje s tumorom bile su odrasle (u dobi od 3-5 godina), sve su bile ženke s različitim stupnjevima deformacija lica i nosa, koje su rezultirale otežanim disanjem. Rendgenološkim pregledom lubanje otkrivena je masa mekane gustoće tkiva koja je potjecala iz nazalne školjke, a koja invadira okolne nazalne strukture. Citološkom pretragom aspirata tkiva pomoću tanke igle, otkrivena je niska invazija karcinomom. Sve su životinje eutanazirane sukladno s etičkim normama, a nosni putovi su pregledani. Mase tkiva različite veličine bile su uklonjene, a histopatološka pretraga je potvrdila dijagnozu enzootskog nazalnog adenokarcinoma.

Ključne riječi: Awassi pasmina ovaca, damask pasmina koza, nazalni tumor, retrovirus 